\section{The Attempt to Degrade the Sanitary Service at the Isthmus}

The following correspondence, which explains itself, is commented on editorially in this issue:

\section{Hon. James R. Mann:}

Dear Sir: The attention of the Committee on Medical Leg. islation of the American Medical Association has been called to H. R. 5155, introduced by you in the House of Representatives, providing for the government of the Canal Zone and the construction of the Panama Canal. An examination of the bill shows that in Section 3, providing for the organization of the canal board, no provision is made for a chief sanitary officer of the same rank as the director, chief engineer and governor. The result of the adoption of the bill in its present form would evidently be the subordination of the sanitary department to the position which it occupied under the first canal board. I am sure that this was not your intention, in view of the great importance of the sanitary department in making the construction of the canal possible. In other words, I am confident that the omission of such a provision is an oversight. I therefore take the liberty of calling your attention to it and shall be glad to learn whether it would not be possible to amend the bill so as to leave the position of the sanitary department unehanged. I shall be very glad to hear from you on this point.

Frederick R. Green,

Secretary, Committee on Medical Legislation.

\section{House of Representatives}

COMMITTEE ON INTERSTATE AND FOREIGN COMMERCE

Dr. Frederick R. Green, Chicago:

Dear Sir: Replying to your recent favor, I beg to say that I am not in favor of making a chief sanitary officer on the Canal Zone of the same rank as the chief engineer. It is not possible to have good government on the zone with a lot of different heads, but under the bill which I introduced the President has full authority to continue the Chief Sanitary Officer and give him as much authority as he now has. It would be impossible to carry on the work of the canal without constant friction if your sugestion was incorporated in the law and I trust that you will not push it. Certainly the sanitation of the canal will be cared for and there is no intention to let down on the character of the work now being performed. JAMES R. MANN, M. C.

\section{Medical Education and State Boards of Registration}

\section{COMING EXAMINATIONS}

California : Los Angeles, December 7. Sec., Dr. Charles L. Tisdale, Butler Bldg., San Francisco.

Delaware: Regular, Dover, December 14 ; Iomeopathic, Wilmington Decemer 14. Secretary of the Medical Council, Dr. H. W. Briggs, Wilmington.

Iow A: State House, Des Moins, Dec. 7-9. Sec., Dr. L. A. Thomas. Kentucky : The Armory, Louisville, December 14. Sec., Dr. J. N. McCormack, Bowling Green.

MARYLAND: 1211 Cathedral St., Baltimore, December 14-17. Sec., MARYLAND: 1211 Cathedral St.,
Dr. J. M. Scott, Hagerstown.

Pervisuania: Regular and Homeopathic, Philadelphia, December 14.17; Felectic Harrisburg, December 14-17. Secretary of the 14.17; Eclectic, Harrisburg, December 14-17. Secretary of the virginia: Ljnchburg, Dec. 14-17. Sec., Dr. R. S. Martin, stuart.

The Medical School as a Part of the University

In the annual address in medicine at Yale University, Prof. W. H. Howell (Science, July 30, 1909, p. 129) points out the remarkable progress which has been made in medical education in this country within the last decade. He, however, calls attention to the fact that by far the greatest progress has been made in the teaching of the medical or biologic sciences. The time of preparation for the clinical years has been greatly lengthened and improved, while in the last two, or clinical, years the progress has been comparatively very slow; so slow in fact, that the methods and quality of instruction in these years, in the majority of American medical schools, is very little improved over that given to the former generation.
The explanation of this is probably to be sought in the fact that the clinical men are too of ten capable practitioners rather than scientific physicians. Too often they are so lacking in an adequate knowledge of laboratory methods and the medical seiences that one is inclined to ask what is the use of giving the student a scientific training if the man who instructs him in diagnosis and treatment neglects to show wherein this knowledge is applicable. Under present conditions so much time and energy are devoted to private practice by the clinical men that original investigation and scientific clinical instruction sadly suffer as a consequence.

As a remedy it is recommended that the clinical professors be paid the full salary of a full professor and be limited in their practice to the University Hospital. Howell thinks that America is at present in a good condition to try such an experiment as well as to carry out the recommendation of the Council on Medical Education of the American Medical Association, that there be added to the present regular course of instruction a year of hospital service as an obligatory part of the requirements for the degree in medicine or for the license to practice medicine.

\section{North Dakota October Report}

Dr. H. M. Wheeler, secretary of the North Dakota State Board of Medical Examiners, reports the written examination held at Grand Forks, Oct. 5-7, 1909. The number of subjects examined in was 14; percentage required to pass, 75 . The total number of candidates examined was 16, all of whom passed. Twelve reciprocal licenses were issued at this examination. The following colleges were represented:

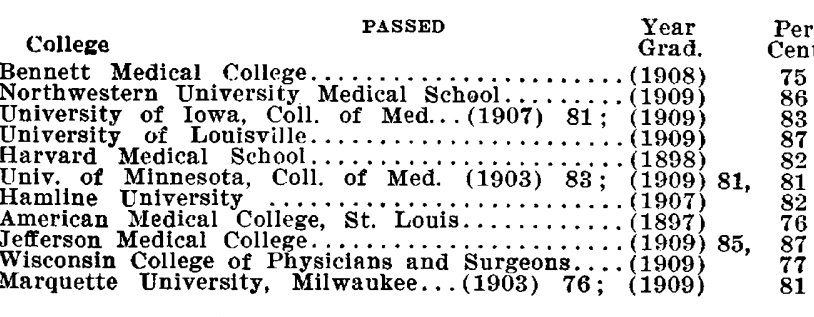

LICENSED THROUGH RECIPROCITY

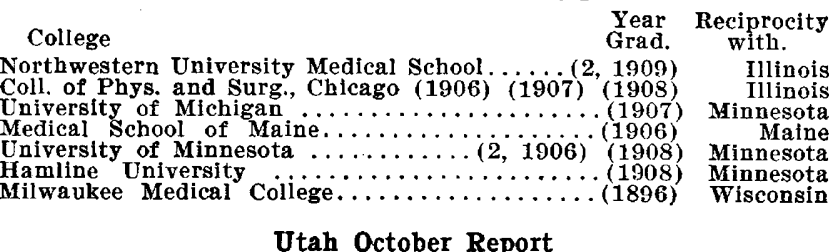

Dr. G. F. Harding, secretary of the Utah State Board of Medical Examiners, reports the written examination held at Salt Lake City, October 4-5, 1909. The number of subjects examined in was 16; total number of questions asked, 100 ; percentage required to pass, 75 . The total number of candidates examined was 5, of whom 3 passed and 2 failed. Seven reciprocal licenses were granted. The following colleges were represented :

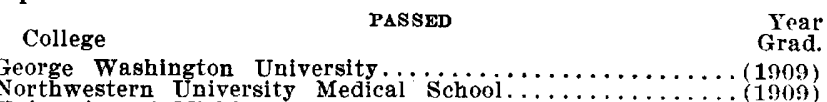

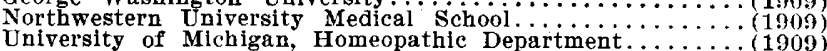

Keokuk Medical College ......................... (1909)

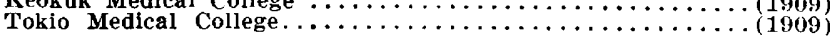

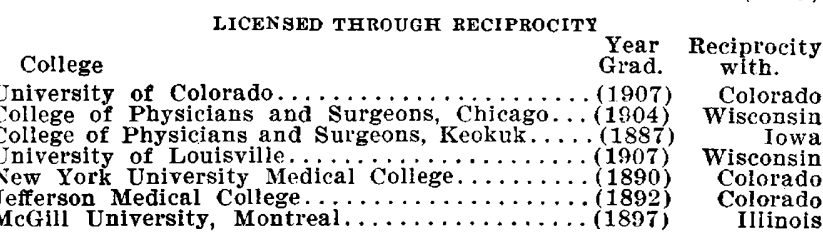

\section{Louisiana October Report}

Dr. F. A. LaRue, secretary of the Louisiana State Board of Medical Examiners, reports the written examination held at New Orleans, Oct. 1-2, 1909. The number of subjects exam. 